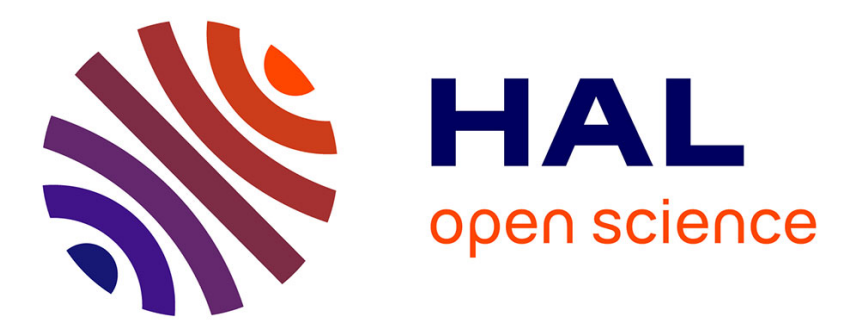

\title{
Micromachined 2D nanoelectrospray emitter
}

S. Arscott, S. Le Gac, C. Druon, P. Tabourier, C. Rolando

\section{- To cite this version:}

S. Arscott, S. Le Gac, C. Druon, P. Tabourier, C. Rolando. Micromachined 2D nanoelectrospray emitter. Electronics Letters, 2003, 39 (24), pp.1702. 10.1049/el:20031099 . hal-02347842

\section{HAL Id: hal-02347842 \\ https://hal.science/hal-02347842}

Submitted on 6 Jan 2021

HAL is a multi-disciplinary open access archive for the deposit and dissemination of scientific research documents, whether they are published or not. The documents may come from teaching and research institutions in France or abroad, or from public or private research centers.
L'archive ouverte pluridisciplinaire HAL, est destinée au dépôt et à la diffusion de documents scientifiques de niveau recherche, publiés ou non, émanant des établissements d'enseignement et de recherche français ou étrangers, des laboratoires publics ou privés. 


\section{Micromachined 2D nanoelectrospray emitter}

\section{S. Arscott, S. Le Gac, C. Druon, P. Tabourier and C. Rolando}

A novel 2D nanoelectrospray emitter for mass spectrometry has been micromachined using photoresist SU-8 on silicon substrates using one-step photomasking. The design contains a reservoir, a capillary slot and an emitter tip. The emitters were successfully tested on an ion trap mass spectrometer. A nanoelectrospray was observed at voltages as low as $0.8 \mathrm{kV}$.

Introduction: The use of micromachining for the fabrication of components in the fields of biology and chemistry [1] is attractive for various reasons: (i) increased reproducibility of the devices, (ii) improved device quality and (iii) batch production. These factors lead to more reliable analysis conditions and higher sample throughput, e.g. in the field of proteomics [2] where a large number of proteins still remain to be characterised using mass spectrometry (MS) techniques which rely on electrospray ionisation (ESI). ESI is currently performed using commercial sources based on capillary tubes. However, such emitters present a number of weaknesses: (i) poorly controlled fabrication, (ii) low analysis reproducibility and (iii) little scope for integration onto a chip. Thus, the application of micromachining techniques to the fabrication of ESI-MS emitters has been suggested $[3,4]$.

In this Letter, we present a novel 2D nanoelectrospray emitter. The design has much in common with that of a fountain pen in that it contains a reservoir for a test liquid and a capillary slot in order to guide the test liquid to a point where electrospray ionisation can be performed via the application of the ionisation voltage.

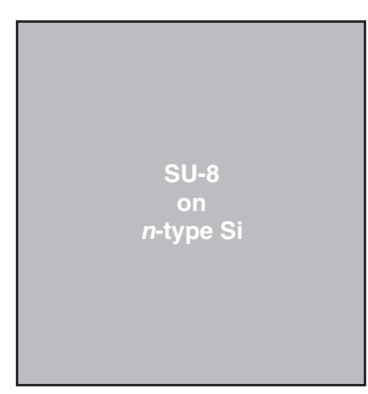

a

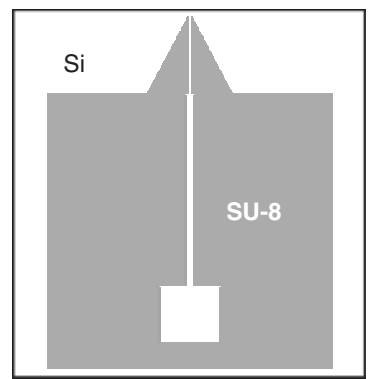

c

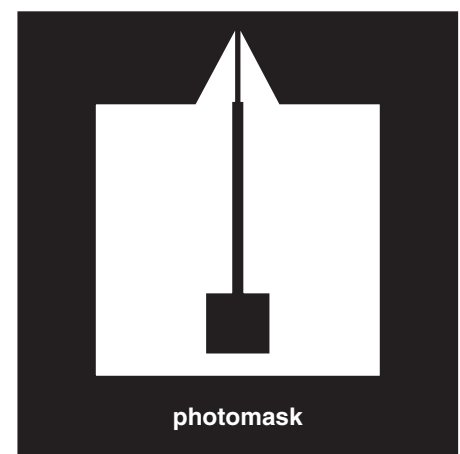

$b$

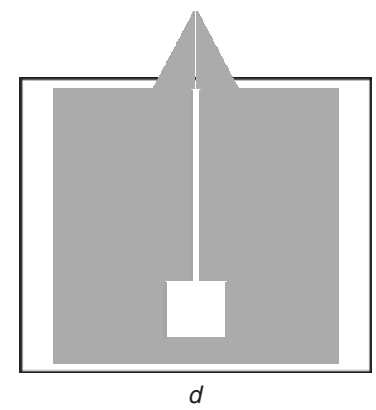

Fig. 1 Fabrication process for 2D ESI emitters

$a$ Spin-coating of SU-8

$b$ One-step UV photomasking stage

$c$ Development of emitters

$d$ Wafer dicing to ensure emitter tips overhang edge of silicon wafer

Source design and fabrication: The emitters are composed of three main elements: (i) a reservoir for the test liquid, (ii) a capillary slot having a length of $2 \mathrm{~mm}$ and (iii) an emitter tip which overhangs the edge of a silicon wafer thus ensuring a point-like effect for the required concentration of the electric field for ESI. The capillary slot leads the test liquid by capillary action from the reservoir to the overhanging emitter tip towards the MS. The emitter tips were approximately $1 \mathrm{~mm}$ long following wafer dicing and had a $40^{\circ}$ point angle. The exterior dimensions of each source were $1 \times 1 \mathrm{~cm}$ to enable easy handling and emitter mounting in order to facilitate the MS tests. A schematic diagram for the fabrication of the emitters is shown in Fig. 1. The photomask was designed using the software Wavemaker $^{\mathrm{C}}$ (BML, London, UK). A photomask was produced using an EBP G5000+ nanomasker (Leica, VA, USA) which contained a total of nine ESI emitters incorporated into the mask design in a $3 \times 3$ array. The emitters were fabricated in a planar fashion using the epoxy-based negative photoresist SU-8 (Microchem, MA, USA) on a $250 \mu \mathrm{m}$-thick 3 inch silicon $n$-type substrate orientated (100). SU-8 is becoming increasingly used for the construction of microfluidic networks [5]. A single $35 \mu \mathrm{m}$-thick layer of SU-8 2035 was spincoated $\left(3000 \mathrm{rpm} / 300 \mathrm{rpms}^{-1} / 30 \mathrm{~s}\right)$ onto the silicon wafer. The photoresist was then pre-baked using a hotplate for $5 \mathrm{~min}$ at $95^{\circ} \mathrm{C}$. A single photomasking stage is then required to define the shape of the emitters using the photomask and exposure to UV radiation. Fig. $1 b$ shows one element of the one-step photomask used to fabricated the 2D emitters. Following UV exposure, a post-bake of the SU-8 was performed for $2 \mathrm{~min}$ at $95^{\circ} \mathrm{C}$ using a hotplate. The SU-8 photoresist is then developed in XP SU-8 developer solution (see Fig. 1c). There were two widths of capillary slots on the mask: 8 and $16 \mu \mathrm{m}$, in the case of the smallest dimension, namely an $8 \mu \mathrm{m}$ slot width, the capillary slot had an aspect ratio of $>4$. The individual emitters were diced along the (100) direction using a technique which ensures that the emitter tips overhang the edge of the silicon wafer (see Fig. 1d). Fig. 2 shows an SEM image of a typical emitter tip which has been fabricated.

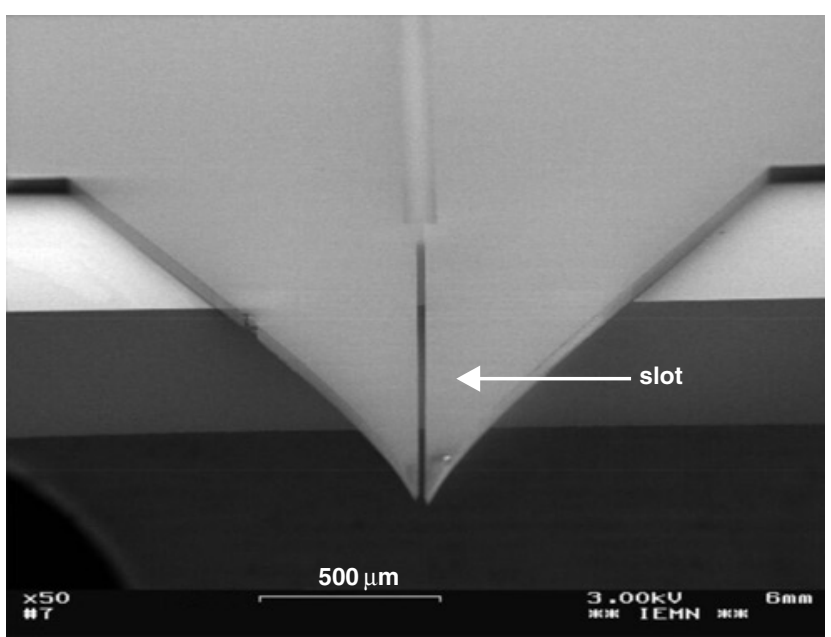

Fig. 2 SEM image of typical 2D ESI emitter fabricated using technique (slot width $=16 \mu \mathrm{m})$

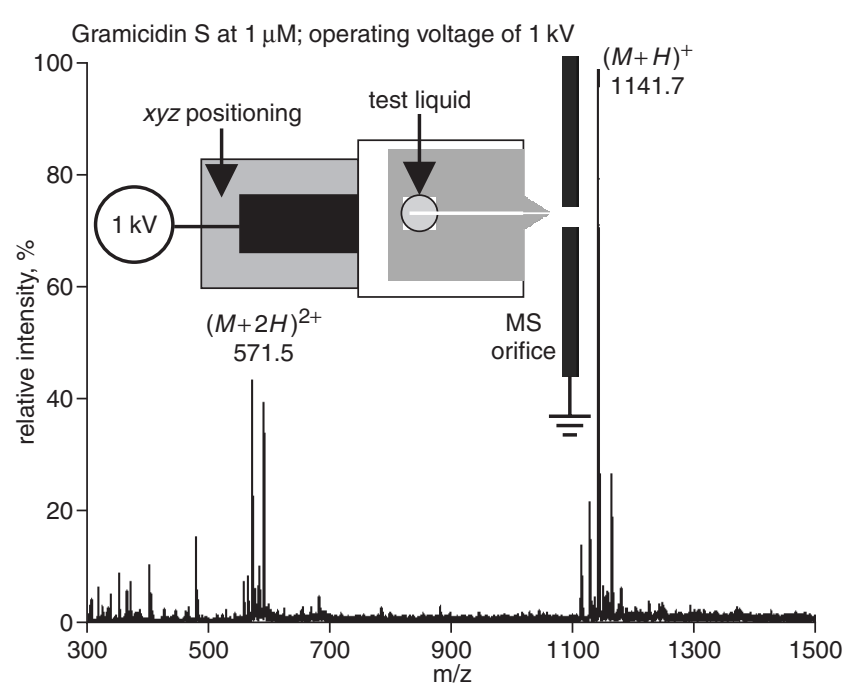

Fig. 3 Resultant test mass spectrum obtained using 2D ESI emitter (slot width $=8 \mu \mathrm{m}$ ) at $1 \mathrm{kV}$ using Gramicidin $S$ at $1 \mu \mathrm{M}$

Inset: Experimental setup used to test micromachined 2D ESI emitters 
Mass spectrometry tests: A plan view of the setup used for the mass spectrometry tests is shown in the inset to Fig. 3. The emitters were tested on an LCQ Deca XP+ ion trap mass spectrometer (Thermo Finnigan, San Jose, CA). The silicon wafer which supported the SU-8 source was mounted on a moving component to be introduced into the ion trap inlet. This moving piece includes a metallic zone on which high voltage (HV) is applied for ESI-MS experiments. The ionisation voltage was applied to the liquid in the reservoir via the $n$-type silicon wafer. The conductivity of the wafer and liquid were sufficient to produce an electrospray upon application of the voltage. The peptide sample $(5 \mu \mathrm{L})$ was dropped into the reservoir of the $2 \mathrm{D}$ source using a micropipette. Following this, the moving component was introduced in the ion trap mass spectrometer inlet and its position was precisely adjusted using the $x y z$ micro-positioning stage.

The sources were tested with standard peptide (Gramicidin S) solutions at $1,5,10 \mu \mathrm{M}$ prepared using a methanol:water (50:50)+ $0.1 \%$ formic acid solvent. The HV supply was in the 0.8 to $1.5 \mathrm{kV}$ range. Upon application of the ionisation voltage a Taylor cone was clearly visible at the end of the capillary slot; this demonstrates the existence of ESI. The total ion current (TIC) signals (not shown here) were stable in all conditions of spraying. The mass spectra were averaged over a $2 \mathrm{~min}$ acquisition period using the Excalibur software (Thermo Finnigan, San Jose, CA). A typical mass spectrum obtained with an $8 \mu \mathrm{m}$ micro-nib source, a HV supply of $1 \mathrm{kV}$ and a sample of $1 \mu \mathrm{M}$ is shown in Fig. 3. A value of $0.8 \mathrm{kV}$ was determined as a lower limit value for this current design of emitters. The signal-to-noise ratio (SNR) was observed to be very good for all experiments that were carried out with the emitters: the analysed species could be identified without doubt. The spraying conditions for these emitters are thus comparable to those used for standard emitter tips (results not shown here). Indeed, a major advantage of this topology is that liquid sample loading is much easier to achieve than for standard capillary tube emitters. Consequently, this source geometry is compatible with the use of robots for the automation of ESI-MS analysis for highthroughput applications.

Conclusions: We have designed and demonstrated a novel 2D nanoESI emitter which contains a reservoir and a capillary slot which leads a test liquid from the reservoir to the emitter tip. The photoresist SU-8 has been used to produce the emitters on silicon wafers using a single photomasking step. The smallest critical emitter tip dimensions on the mask were $8 \times 35 \mu \mathrm{m}$. Excellent performances were obtained in mass spectrometry experiments using the 2D ESI emitters, the peak intensity being comparable to that which is observed for standard capillary tube-based nanoESI emitters at a voltage of $1 \mathrm{kV}$.

(C) IEE 2003

Electronics Letters Online No: 20031099

1 September 2003

DOI: 10.1049/el:20031099

S. Arscott, C. Druon and P. Tabourier (Institut d'Electronique, de Microélectronique et de Nanotechnologie, UMR, CNRS 8520, Cité Scientifique, Villeneuve d'Ascq Cedex, France)

E-mail: steve.arscott@iemn.univ-lille1.fr

$\mathrm{S}$. Le Gac and C. Rolando (Laboratoire de Chimie Organique et Macromoléculaire, Université des Sciences et Technologies de Lille, UMR, CNRS 8009, Villeneuve d'Ascq Cedex, France)

\section{References}

1 KOCH, M., EVANS, A, and BRUNNSCHWEILER, A.: In PETHIG, R (Ed.): 'Microfluidic technology and applications' (Research Studies Press, UK, 2000), Chap. 6, pp. 151-287

2 FIGEYS, D., and PINTO, D.: 'Proteomics on a chip: promising developments', Electrophoresis, 2001, 22, pp. 208-216

3 GRISS, P., MELIN, J., SJODAHL, J., ROERAADE, J., and STEMME, G.: 'Development of micromachined hollow tips for protein analysis based on nanoelectrospray ionisation mass spectrometry', J. Micromech. Microeng., 2002, 12, pp. 682-687

4 LIN, L., and PISANO, P.: 'Silicon processed micro-needles', IEEE J. Micromech. Sys., 1999, 8, pp. 78-84

5 LIN, C.-H., LEE, G.-B., CHANG, B.-W., and CHANG, G.-L.: 'A new fabrication process for ultra-thick microfluidic microstructures utilizing SU-8 photo resist', J. Micromech. Microeng., 2002, 12, pp. 590-597 